\title{
New Findings in the Signaling Pathways of cis and trans Platinum lodido Complexes' Interaction with DNA of Cancer Cells
}

\author{
Adoración G. Quiroga, ${ }^{* \dagger}{ }^{\dagger}$ Marta Cama, ${ }^{\dagger \dagger}$ Natalia Pajuelo-Lozano, Amparo Álvarez-Valdés, ${ }^{\dagger}$ \\ and Isabel Sanchez Perez $*$,
${ }^{\dagger}$ Inorganic Chemistry Department, Universidad Autónoma de Madrid and IAdChem Universidad Autónoma de Madrid, Madrid 28049, Spain
${ }^{\ddagger}$ Biochemistry Department, Faculty of Medicine, Instituto de Investigaciones Biomédicas Alberto Sols. CSIC-UAM, Madrid 28029, Spain

Supporting Information

\begin{abstract}
We have selected a series of aliphatic amine platinum compounds bearing chloride and/or iodide as the leaving groups. The complexes' cytotoxicity and interaction with DNA indicated differences in the reactivity. Now, we are reporting on the analysis of their molecular mechanism of action on gastric cancer cells. Our data reveals differences between them. Chlorido drugs showed similar behavior to cisplatin; they both required p53 to induce apoptosis but only cis-ipa showed DNA damage requirement for apoptosis induction. On the contrary, cis and trans iodido induced cell death independent of p53 activity, and they induced cell death through Bid activation, so their toxicity could be enhanced in a combined treatment with novel

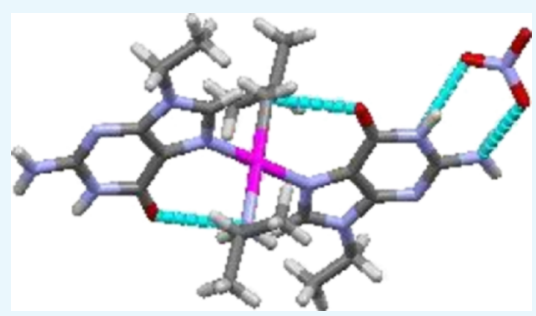
Bcl-2 protein family inhibitors. We also report the structural features of the DNA adduct for one of the complexes by X-ray diffraction. These findings represent a step forward in the search for new platinum-derived agents more specific and effective in the treatment of cancer.
\end{abstract}

\section{INTRODUCTION}

Cisplatin is a clinical drug used for the treatment of solid tumors; however, cisplatin can produce relevant disadvantages that are difficult to overcome, as for example the cellular development of resistance (intrinsic or acquired). In addition, treatment with cisplatin manifests systemic side effects, such as neurotoxicity among others. Therefore, obtaining metal derivatives of platinum that are equal or more effective than cisplatin will be of great benefit in the cure of the disease.

As we reported on the iodido complexes' potential antitumoral action possibly caused by their peculiar reactivity toward biological targets, ${ }^{1}$ there has been a new research trend with reports trying to better understand iodido complexes' activity. The reevaluation of cis and trans iodido derivatives' cytotoxicity showed their efficiency and their interaction study versus model proteins indicate a possible different mechanism of action. ${ }^{2}$ Further work proved this protein interaction of these complexes by X-ray diffraction. ${ }^{3}$

As DNA is cisplatin's main target, the studies of reevaluated iodide complexes with DNA are an important step to take into consideration. The basic models (cisplatin and its iodido analogues) were studied using oligo deoxyribo nucleotides as DNA models, indicating the same type of interaction toward guanine (leading to adducts containing $\left(\mathrm{Pt}\left(\mathrm{NH}_{3}\right)_{2}{ }^{2+}\right)$ with the iodido derivative always being more reactive than cisplatin. ${ }^{4}$ Another example is the work performed by Dvořak et al., varying the amine ligand and substituting for bulkier azaindoles. ${ }^{5}$ They studied the cytotoxic activity of iodide azaindole complexes and looked at the molecular level mechanism to find a decrease of tumor suppressor p53 amount, which can agree with our previous observations with the aliphatic amine iodido compounds.

On putting this information together, it is clear that iodide complexes interact with DNA, but we need more data about the possible differences at molecular level and in particular, about the signaling pathways, to deeply analyze a broader spectrum of interactions before and after DNA damage. For this work, we will be using gastric cancer cell lines, with which we have recently reported the molecular processes involved in cisplatin-induced apoptosis. ${ }^{7}$

\section{RESULTS}

We selected some of the reported structures, and we synthesized and characterized the following series of compounds: cis- $\left[\mathrm{Pt}(\mathrm{ipa})_{2} \mathrm{Cl}_{2}\right], \mathbf{1}$, trans- $\left[\mathrm{Pt}(\mathrm{dma})(\mathrm{ipa}) \mathrm{Cl}_{2}\right], \mathbf{2}$, cis- $\left[\mathrm{Pt}(\mathrm{ipa})_{2} \mathrm{I}_{2}\right], 3$, and trans- $\left[\mathrm{Pt}(\mathrm{ipa})_{2} \mathrm{I}_{2}\right], 4$ (depicted in Chart $1)$. All data collected with these complexes agreed with those previously reported, ${ }^{1,6,8}$ therefore we performed the following assays.

We began analyzing the viability in MNK45 gastric cancer cells after treatment with the selected series of platinum compounds and using cisplatin (CDDP) as a reference. The results are shown in Figure 1 we observed that the survival decreased in a dose-dependence manner with the following

Received: September 2, 2019

Accepted: November 15, 2019

Published: December 3, 2019 


\section{Chart 1. Structure of Complexes 1 to 4}
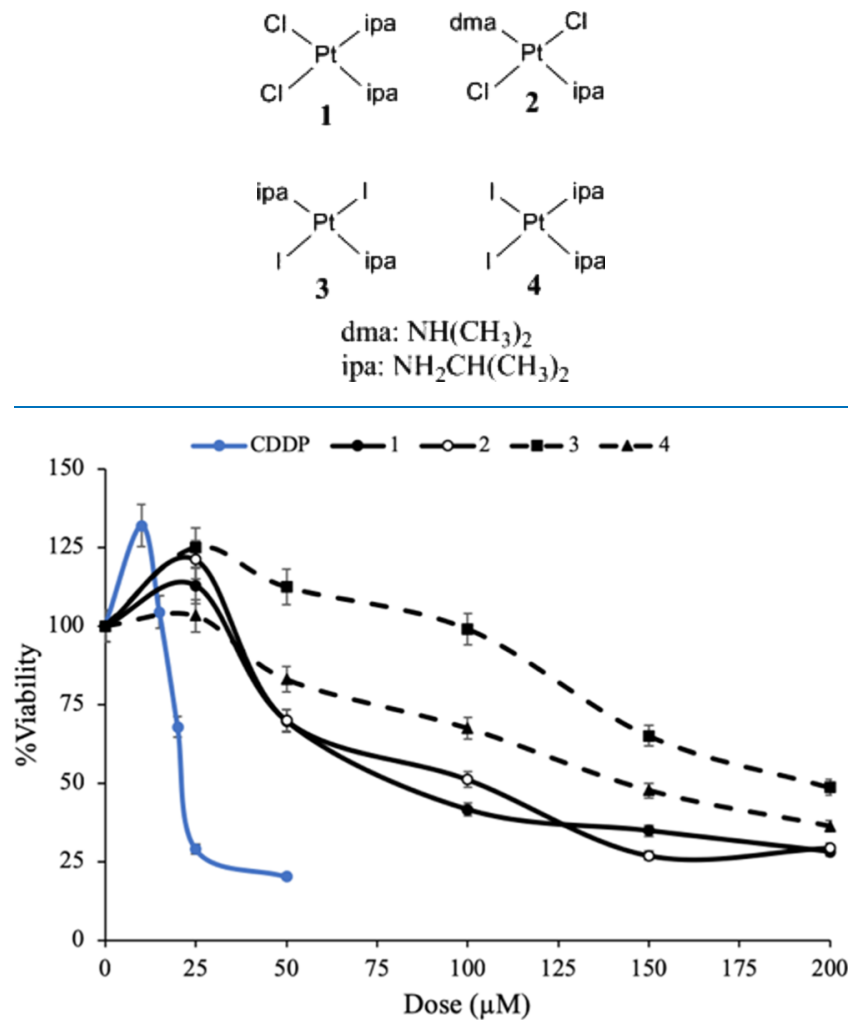

Figure 1. Cell viability results of cisplatin and complexes $\mathbf{1}$ to $\mathbf{4}$ for the MNK45 gastric cancer cells.

$\mathrm{IC}_{50}$ : CDDP $(20 \mu \mathrm{M}), \mathbf{1}(80 \mu \mathrm{M}), 2(100 \mu \mathrm{M}), 3(180 \mu \mathrm{M})$, and $4(140 \mu \mathrm{M})$. The compounds are less cytotoxic than cisplatin, but these complexes show good values in other type of cell lines, in particular, those which are not dependent on p53. ${ }^{6}$ Therefore, we analyzed the compound's effect in the HCT116 wild type (WT) and HCT116 p53 knock out (KO) cell lines.

Table 1 shows the $\mathrm{IC}_{50}$ values from HTC-116 cells (HCT$116 \mathrm{WT}$ and $\mathrm{p} 53 \mathrm{KO}$ ) after treatment with the compounds.

Table 1. $\mathrm{IC}_{50}$ for Complexes 1-4

\begin{tabular}{lcc} 
& $\mathrm{WT} \mathrm{IC}_{50}(\mu \mathrm{M})$ & $\mathrm{p} 53^{-/-} \mathrm{IC}_{50}(\mu \mathrm{M})$ \\
$\mathrm{CDDP}$ & $15.34 \pm 2.17$ & $48.75 \pm 4.80$ \\
$\mathbf{1}$ & $91.20 \pm 9.90$ & $172.18 \pm 12.24$ \\
2 & $66.37 \pm 3.40$ & $133.35 \pm 15.21$ \\
3 & $55.71 \pm 3.22$ & $85.50 \pm 10.73$ \\
4 & $28.64 \pm 2.90$ & $66.07 \pm 5.38$ \\
\hline
\end{tabular}

Our results show that in the absence of p53, HTC116 are more resistant to CDDP than the WT HCT116 cells. The treatment with compounds 1 and 2 shows an increase in the $\mathrm{IC}_{50}$ when cells lack p53. In contrast, cells treated with compounds 3 and 4 do not exhibit the big difference in viability that is shown by $\mathbf{1}$ and $\mathbf{2}$ independently of the genotype (Figure 2). Although compounds 3 and 4 show a difference within the range of cisplatin, these data have to be evaluated to find if the contribution of $\mathrm{p} 53$ in the cell death is partial and/or other pathways are involved in the process.

The cytotoxicity result in HTC-116 encouraged us to evaluate p53 activation in MNK45 after treatment with the different compounds and CDDP as a control. To do that, we analyzed the phosphorylation of Ser15 in p53, which is indicative of activation by WB. The results indicate that $\mathrm{p} 53$ is activated in response to cisplatin and compound 2 in a persistent manner up to $48 \mathrm{~h}$. In contrast, the treatment with compound 1 induced p53 phosphorylation, transitory with a maximum peak at $24 \mathrm{~h}$ (Figure 3). Surprisingly (however), no activation of p53 was observed after treatment with compound 3 and 4.

Next, we analyzed the molecular markers that indicate apoptosis induction. We observed the activation of caspase 3 with the whole series of compounds. To corroborate these results, we analyzed the proteolysis of PARP (specific substrate of caspase 3 ) that shows a clear proteolysis, according to caspase 3 activation (Figure 4). This effect is also observed for cisplatin, as previously reported. In the end, apoptosis induction is corroborated.

CDDP activates apoptosis mainly through the intrinsic pathway, and then we explored the intrinsic apoptosis pathway activation by the compounds. First, we study the protein levels of different members of BcL2 family. We observed induction of the proapoptotic protein, Puma after treatment with CDDP and $\mathbf{1}$ but not $\mathbf{2}$. In fact compound $\mathbf{2}$ does not show differences at any time after treatment. In contrast, Puma protein is not induced after exposure to 3 and 4 . The pro-apoptotic protein, Bax increases in response to CDDP and 1, whereas compound 2 slightly induces Bax. The iodide complex 3 instead provoked Bax induction, as we observed a small but clear level decrease at $48 \mathrm{~h}$. Complex 4 does not modify Bax expression (Figure 5).

We observed induction of the proapoptotic protein, Puma after treatment with CDDP, 1, and 2 (Figure 5). However, 3 and 4 do not induce Puma. P53 contributes to Puma induction; therefore, this result is in agreement with the p53 levels previously observed (Figure 3). The pro-apoptotic protein, Bax increases in response to CDDP and $\mathbf{1}$, whereas compound 2 slightly induces Bax. The iodide complexes (3 and 4) do not modify Bax expression (Figure 5).

$\mathrm{BID} 1$ protein belongs to $\mathrm{BH} 3-$ only $\mathrm{Bcl} 2$ subfamily; it is a cytoplasmic protein that once proteolyzed, translocates to the mitochondria membrane binding to BAX, which allows Cyt $\mathrm{C}$ release and caspase 9 and 3 activation. Then, BID1 is activated by CDDP, 1, and 2 after 6 h of treatment; however, 3 and 4 provoke only a transitory activation, with a highest point after $6 \mathrm{~h}$.

Finally, the antiapoptotic Mcll expression analysis after $6 \mathrm{~h}$ of treatment shows that CDDP produces clear degradation as it is described in the literature after $48 \mathrm{~h}^{7}$ Compound 1 shows the same profile. No degradation is observed neither with 2 nor with $\mathbf{4}$, but a surprisingly marked degradation is observed with $3 \mathrm{~h}$ treatment.

It is known that JNK and p38 could phosphorylate MCL1 and induce its degradation. ${ }^{9-11}$ We studied the MAKPs activation after treatment with the compounds; the results show a transient activation of $\mathrm{p} 38$ when treated with CDDP, $\mathbf{1}$, and $\mathbf{2}$, and a persistent activation with $\mathbf{3}$ and $\mathbf{4}$ (Figure 6). Only 2 and 3 show clear but transitory activation of JNK with the highest peak after $6 \mathrm{~h}$. The entire compound series activates ERK, showing similar profile with the exception of $\mathbf{2}$ (which activates only in a transitory way). These results may indicate that MCL1 degradation is produced by p38 phosphorylation.

DNA is the main cellular target for platinum complexes, which leads to the activation of different checkpoints in the cell cycle. We then analyzed the cell cycle profile after treatment 

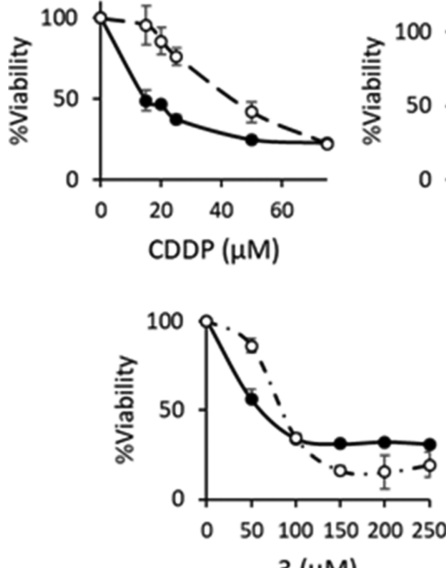

$3(\mu \mathrm{M})$
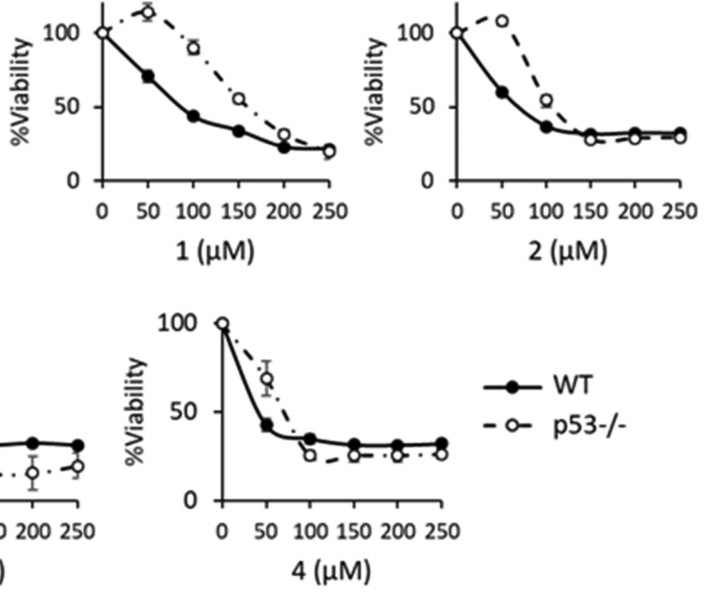

Figure 2. Cell viability results of the complexes in HCT116 wild type and p53 KO cell lines. CDDP was used as a reference. Cell survival percentage of $\mathrm{HCT} 166^{\mathrm{WT}}$ and HCT116 $\mathrm{p} 53^{-/-}$cells after $72 \mathrm{~h}$ of CDDP or compounds treatment. Cells were treated with increasing concentrations of CDDP $(0-75 \mu \mathrm{M})$ or compounds $(0-250 \mu \mathrm{M})$ The percentage of viable cells was quantified by the MTS assay. Data represent the mean values obtained in three experiments performed in quadruplicate.

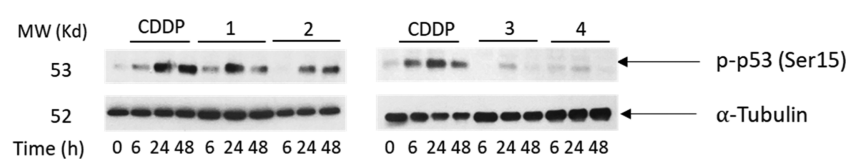

Figure 3. Complex 1 and 2 induces p53 activation in MKN45 cells. Cells were treated with the complexes CDDP, 1, 2, 3, and 4 at IC50 dose for each compounds, and harvested at the indicated times. P53 total levels and phosphorylated were detected by Western blot using specific antibodies. Tubulin was used as a control.

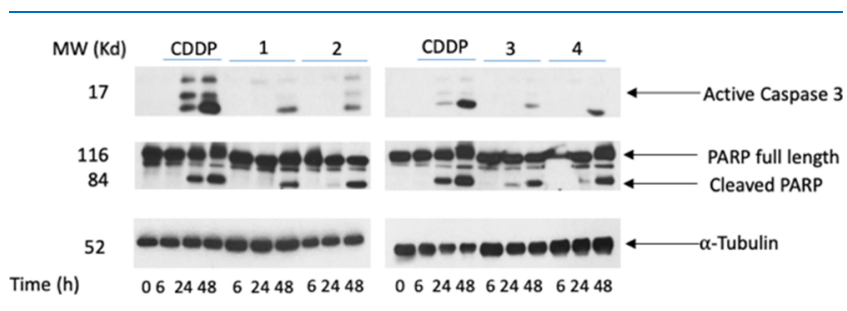

Figure 4. Caspase- 3 activation and PARP proteolysis is detected after treatment with CDDP, 1, 2, 3, and 4 in MKN45 cells. Cells were treated as in Figure 3. Caspase 3 and PARP were detected by using specific antibodies.

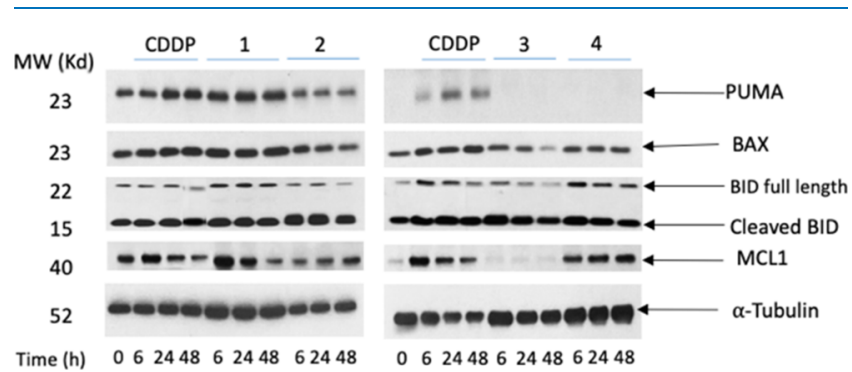

Figure 5. Bcl-2 protein family members analyzed by western blot from MKN45 cells treated with CDDP, 1, 2, 3, and $\mathbf{4}$ as in Figure 3. Proteins Puma, Bax, Bid, and MCL1 were detected by using specific antibodies. Tubulin was used as the control.

with the drugs by flow cytometry on the cancer cells. The results showed an increase in phase $S(54.2 \%)$ for the cells treated with CDDP, which is indicative of intra $S$ checkpoint activation. Compound 1 provokes an increase of cells in phase $S$ (29\%) and phase G2/M (31.3\%), whereas the rest of the

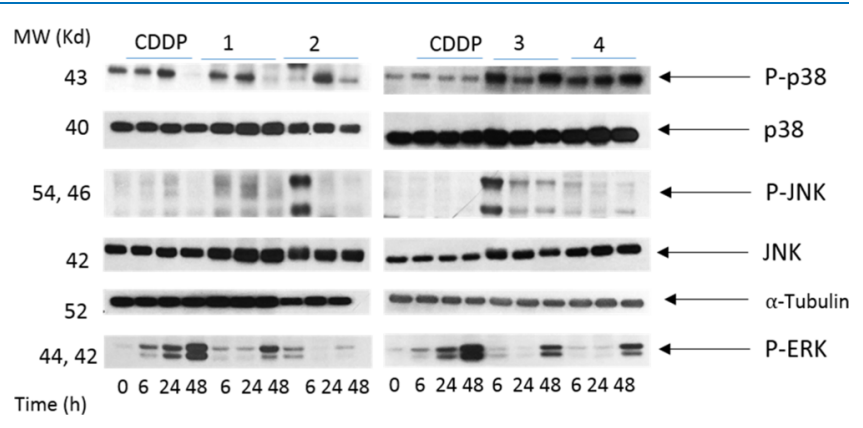

Figure 6. MAP Kinase members analyzed by western blot from MKN45 cells treated with CDDP, 1, 2, 3, and 4.

series produced such increase at the G2/M checkpoint (34.5\% 2; 31.6\%: 3; and 39.8\%: 4) (Figure 7, Table 2).

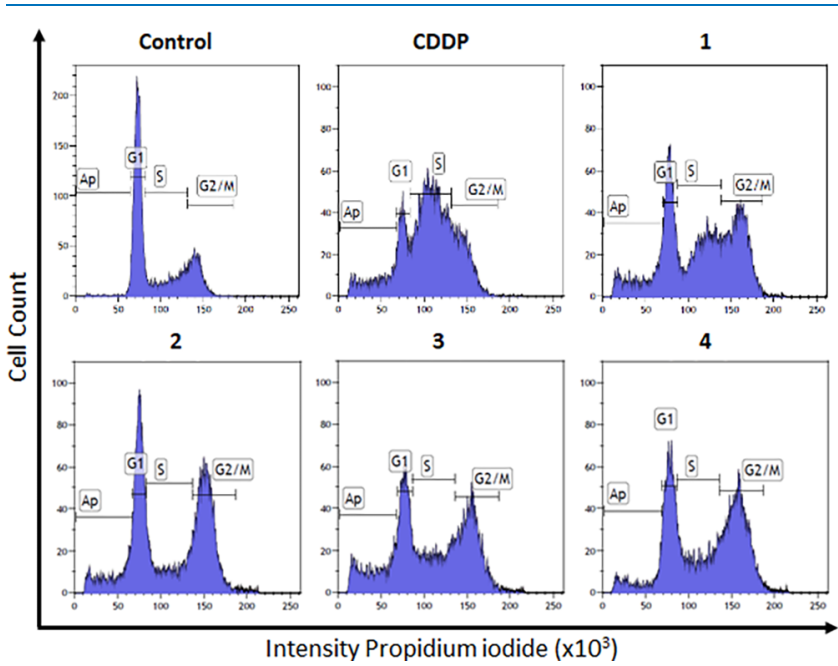

Figure 7. Cell cycle profile of MKN45 cells after treatment with the complexes. DNA content was assessed by flow cytometry, and cell cycle distribution was analyzed using Cell Quest Pro software. Table 2 shows the percentage of each cell phase, which is given as the mean of three experiments. G2/M: cells in G2 or mitosis; S: cells in phase of synthesis of DNA; G1: cells in G1, apoptosis. 
Table 2. Percentage of Cells in Each Cell Cycle Phase after Treatment with the Drugs

\begin{tabular}{lcllc} 
& apoptosis & G1 & \multicolumn{1}{c}{$\mathrm{S}$} & $\mathrm{G} 2 / \mathrm{M}$ \\
control & 2.8 & 55.6 & 21.5 & 19.4 \\
CDDP & 12.4 & 14 & 54.2 & 18.9 \\
$\mathbf{1}$ & 15.5 & 22.7 & 29.7 & 31.3 \\
$\mathbf{2}$ & 15.5 & 30.2 & 17.5 & 34.5 \\
$\mathbf{3}$ & 21.3 & 20.8 & 24.4 & 31.6 \\
$\mathbf{4}$ & 10 & 24.1 & 23.5 & 39.8 \\
\hline
\end{tabular}

CDDP requires DNA damage during the S-phase to induce apoptosis. In order to know if the drugs share this requirement, we synchronized the cell in G1 by using Palbociclib $(1 \mu \mathrm{M})$ and then treated with the drugs (complexes 1 to 4). Our results showed that $\mathbf{1}$ and CDDP produce a lesion on phase $S$ in order to induce cell death, whereas none of the compounds of the series causes such lesion. This result indicates that the apoptosis induction by $\mathbf{2}, \mathbf{3}$, and 4 could start at the phase G2/ M (Figure 8).
As at the last step, we prove the reactivity of the complexes at the molecular level with a small model of DNA. The treatment of trans- $\left[\mathrm{Pt}(\mathrm{ipa})_{2} \mathrm{I}_{2}\right]$ with two equivalents of $\mathrm{AgNO}_{3}$ forced the aqua-complex formation which reacts with two equivalents of 9-EtG (9-ethyl guanine) to produce the complex trans- $\left[\mathrm{Pt}(9-\mathrm{EtG})_{2}(\mathrm{ipa})_{2}\right]\left(\mathrm{NO}_{3}\right)_{2}$, where the iodide groups are replaced by the base.

The structure in Figure 9 shows a mononuclear adduct where the Pt atom is bound to two molecules of 9-EtG through N7 in a square planar geometry similarly to other examples of refs 12-14. Both 9-EtG molecules are coplanar, whereas isopropylamine ligands are $180^{\circ}$ twisted giving the most stable conformation to the molecule. This conformation shows hydrogen bonding interaction between $\mathrm{O}_{1}$ from the carbonyl group of $9 \mathrm{EtG}$ and hydrogen of the $-\mathrm{NH}_{2}$ group from isopropylamine. This kind of interaction has been described to stabilize similar structures. ${ }^{15,16}$ The distance of $2.249 \AA$ indicated strong intramolecular interaction which is the most significant data, as it might potentially hinder the 9-EtG ligands from rotating freely around $\mathrm{Pt}_{1}-\mathrm{N}_{2}$ when binding to any
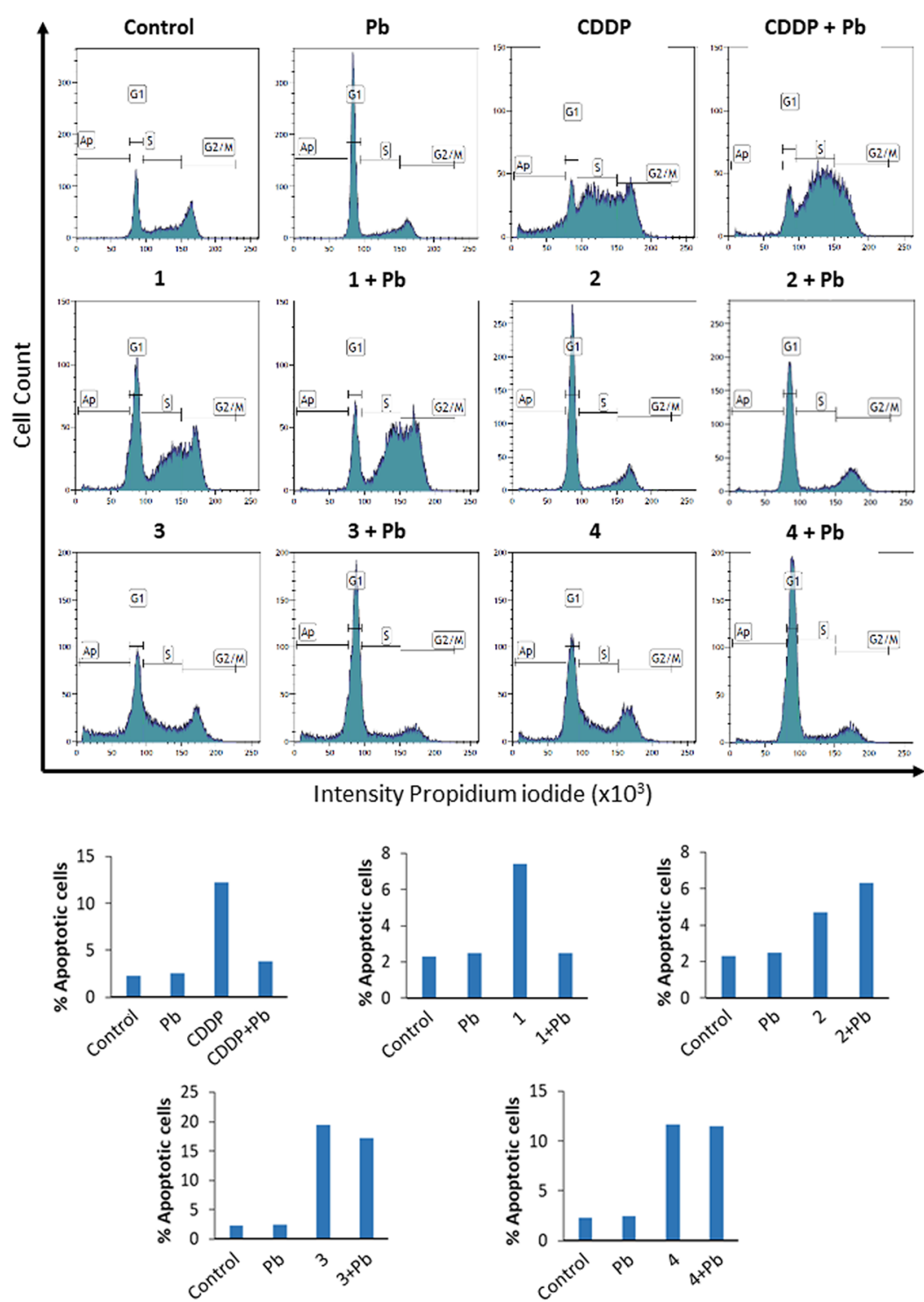

Figure 8. Apopstosis percentage of MKN45 cells after synchronizing with Palbociclib $(1 \mu \mathrm{M})$ for $18 \mathrm{~h}$ and the complexes. DNA content was assessed by flow cytometry, as in Figure 7. Results of the compounds in \% synchronized culture cell by using Palbociclib. Ap: apoptosis. 


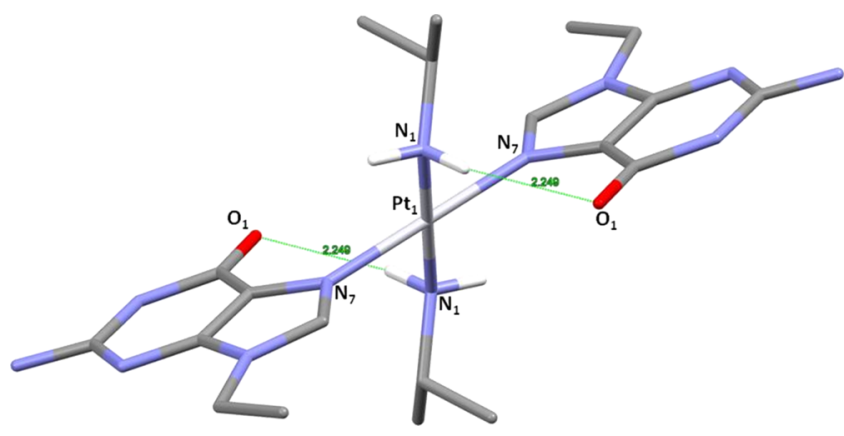

Figure 9. Structure of the complex trans- $\left[\mathrm{Pt}(9-\mathrm{EtG})_{2}(\mathrm{ipa})_{2}\right]\left(\mathrm{NO}_{3}\right)_{2}$. target. $^{17}$ The crystal structure also shows intermolecular hydrogen bonds that involve the nitrate contraction linked by a series of $\mathrm{NH} \mathrm{O}$ contacts. As can be seen in Figure 10, they are responsible for solid-state packaging.

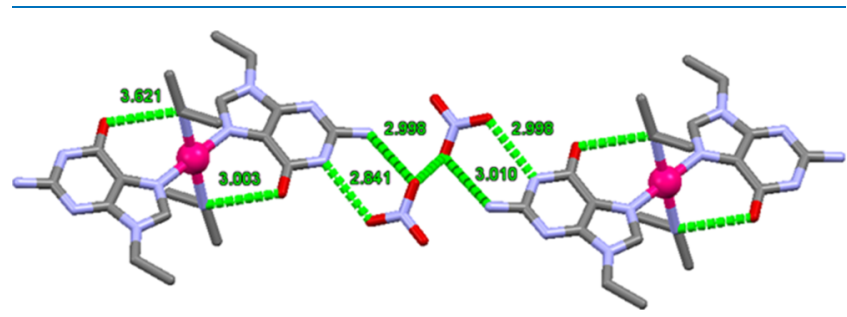

Figure 10. Molecules arrangement in complex trans-[Pt(9$\left.\mathrm{EtG})_{2}(\mathrm{ipa})_{2}\right]\left(\mathrm{NO}_{3}\right)_{2}$ crystal structure.

\section{DISCUSSION}

Based on the efficacy of CDDP (in spite of some of its side effects) and trying to find a clear signaling pathway for the iodide and chlorido compounds, we have analyzed the cytotoxic activity versus the gastric cancer cell line (MKN45) for four cis and trans selected complexes. The complexes show aliphatic amines in their structure and chloride and iodide as the leaving groups.

The compounds, together with CDDP, are capable to decrease the MKN45 cell survival, even though CDDP needs lower doses to produce the same percentage of cell death. It is well known that every cancer cell is different, and as we mentioned before, iodide complexes can be active in cancer cells from different tumors. ${ }^{2}$ In fact, HCT 116 cell lines results showed lower $\mathrm{IC}_{50}$ values than those observed in MKN45.

p53 is a tumor suppressor protein which is mutated in more than the $50 \%$ of tumors; therefore, this finding is of a vital importance in the treatment of tumors p53 null. Mutation on the p53 gene is involved in CDDP resistance in cancer as a consequence of loss of the ability of p53 to transactivate Bax and Puma. ${ }^{18,19}$

The bigger difference in the viability data of complexes 1 and 2 compared with cisplatin indicates a very clear p53 dependence, whereas complexes 3 and 4 did not show that difference. Moreover, complexes $\mathbf{1}$ and $\mathbf{2}$ induce apoptosis and p53 transcriptional dependence genes (Puma and Bax) as cisplatin does. However, the data indicate that the cell death produced by complexes 3 and 4 might only be dependent partially on p53 in spite of the $30 \mu \mathrm{M}$ difference in the genotype. Complexes $\mathbf{1}$ and $\mathbf{4}$ do not induce PUMA and BAX, which are the genes induced by $\mathbf{1}, \mathbf{2}$, and cisplatin. ${ }^{18}$ DNA is the target for chlorido and iodido complexes; based on the differences observed in the reactivity, we thought that the iodido complexes could have some structural differences when binding to DNA. Nucleotides are of a common use in molecular biology studies, and they can also serve to achieve more information about the structural nature of the DNA adducts formed by platinum complexes, in particular 5'-GMP. In our case, we have used 9-EtG as a small DNA model base because this molecule is smaller than nucleotides or plasmidic DNA and more soluble in organic solvents than 5'-GMP, which is also a very convenient model to use for NMR monitoring studies. All these models of DNA help to evaluate the platinum compounds' reactivity and allow the final adducts characterization by different techniques and ideally by X-ray diffraction. The reactivity of trans- $\left[\mathrm{Pt}(\mathrm{ipa})_{2} \mathrm{I}_{2}\right]$ with 9-EtG produces the formation of the adducts more rapidly than the cis counterpart, ${ }^{2}$ leading to the final isolation of the bisadduct trans- $\left[\mathrm{Pt}(9-\mathrm{EtG})_{2}(\mathrm{ipa})_{2}\right]\left(\mathrm{NO}_{3}\right)_{2}$ when forcing the conditions. In this article, we report the $\mathrm{X}$-ray resolution of the final adduct, which supports the classical reactivity of the trans de $\mathrm{Pt}^{\mathrm{II}}-\mathrm{I}$ versus DNA hypothesized in our previous work. ${ }^{2}$ We also report hydrogen bonding that can prevent the rotation of the molecule around the $\mathrm{Pt}_{1}-\mathrm{N}_{2}$ bond and be the direct structural feature produced by the platinum complex in the DNA molecule.

The analysis of the intrinsic apoptotic pathway induced by the compounds has revealed some important differences; compounds 1 and 3 generate an intrinsic apoptosis pathway similarly to CDDP inducing mitochondria perturbation. However, compound $\mathbf{4}$ seems to follow a different profile, and possibly more pathways are involved in its action. One possibility might be that compound $\mathbf{4}$ could induce cell death by the extrinsic pathway or by related receptors. Possibly the activation of caspase 8 will support this hypothesis and further studies will be carried out to explore this possibility. Therefore, compound 4 toxicity could be enhanced in a combined treatment with novel MCL1 inhibitors under development. ${ }^{20}$ We have also demonstrated that compound 2, 3, and $\mathbf{4}$ induce cell death independently of replicative stress. Apoptosis is activated from $\mathrm{G} 2 / \mathrm{M}$, differently from CDDP (whose welldefined target is DNA), but cell death is induced by replicative stress along the $S$ phase.

Compound 2 shows in general a midway behavior between CDDP and iodide complexes, and in particular the fact that JNK activates only in a transitory way could be related with a higher repair capacity of the DNA lesion.

Figure 11 shows a summary of the apoptotic pathway induced by the drug. We propose that iodide drugs increased cell death independent of $\mathrm{p} 53$, which is very promising for tumors with p53 mutated. Complex 2 could be used in combination with other drugs as a mimic of $\mathrm{BH}^{-}$-only proteins to increase the activity. In summary, we have demonstrated that the synthetic variations on platinum complexes can modulate the interaction with these targets and the use of that information is very relevant for pharmaceutical purposes.

\section{MATERIALS AND METHODS}

4.1. Cell Lines. MKN45 and HCT116 human gastric adenocarcinoma cell lines were acquired from ATCC and cultured in RPMI medium or McCoy's 5a medium modified (Gibco), complemented with 10\% FBS. Cultures were kept at $37^{\circ} \mathrm{C}, 5 \% \mathrm{CO}_{2}$, and $95 \%$ humidity. MKN45 cells are wild type for TP53. Mycoplasma contamination tests are frequently run in our laboratory. 


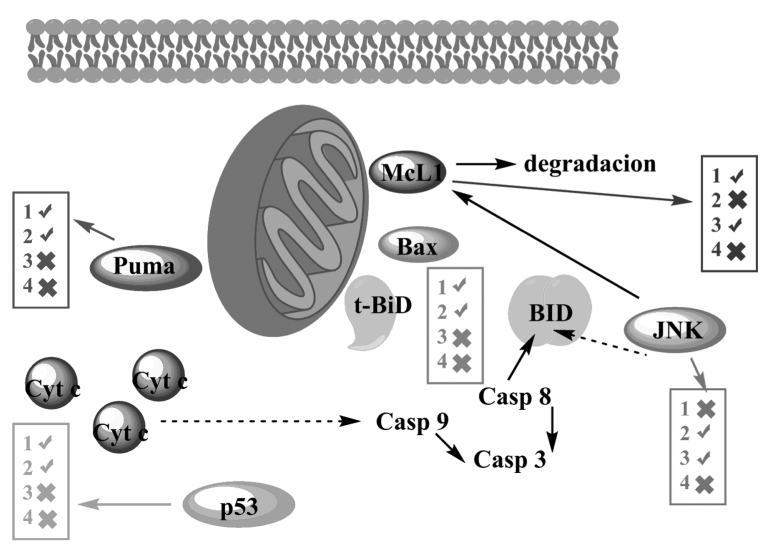

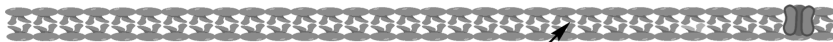

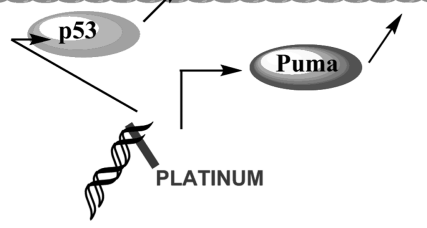

Figure 11. Apoptotic pathway and targets for complexes 1, 2, 3, and 4.

4.2. Chemicals. CDDP was kindly supplied by Ferrer FARMA. The compounds used for the assays (1, 2, 3, and 4) were synthesized following reported procedures, briefly described in the Supporting Information Section $\mathrm{S}^{20}{ }^{20}$ The solution for the MTS assay: CellTiter 96 AQueous One Solution Cell Proliferation Assay was acquired from Promega.

4.3. Reaction of trans-[Pt(ipa $\left.)_{2} \mathrm{I}_{2}\right]$ with 9-EtG: trans$\left[\mathrm{Pt}(9-\mathrm{EtG})_{2}(\mathrm{ipa})_{2}\right]\left(\mathrm{NO}_{3}\right)_{2}$. A solution of $\mathrm{AgNO}_{3}(16.5 \mathrm{mg}$, $0.097 \mathrm{mmol}$ ) in $0.2 \mathrm{~mL}$ of $\mathrm{H}_{2} \mathrm{O}$ was added to a solution of complex $3(27 \mathrm{mg}, 0.048 \mathrm{mmol})$ in acetone and stirred at room temperature in the dark for $10 \mathrm{~min}$. The mixture was filtered and the resulting solution mixed with a freshly prepared solution of $9 \mathrm{EtG}(17.3 \mathrm{mg}, 0.097 \mathrm{mmol})$ in $0.3 \mathrm{~mL}$ of a solution of acetone $/ \mathrm{H}_{2} \mathrm{O}(2: 1)$, stirred at room temperature for $24 \mathrm{~h}$, and allowed to stand until single crystals were formed and isolated. The final compound trans-[Pt(9-EtG) $\left.)_{2}(\text { ipa })_{2}\right]$ $\left(\mathrm{NO}_{3}\right)_{2}$ was shiny white. Anal. Calc. for $\mathrm{PtC}_{20} \mathrm{H}_{36} \mathrm{~N}_{14} \mathrm{O}_{8} \cdot \mathrm{H}_{2} \mathrm{O}$ : C, 29.50; H, 4.70; N, 24.64\%. Found: C, 29.22; H, 5.00; N, 24.48. The structural features of trans-[Pt(9-EtG $\left.)_{2}(\text { ipa })_{2}\right]$ $\left(\mathrm{NO}_{3}\right)_{2}$ were unambiguously proven by X-ray diffraction. Data collection was performed on a Bruker Kappa Apex II (X8 APEX, Bruker, Rivas-Vaciamadrid, Madrid, Spain) area detector X-ray diffractometer using a graphite-monochromated Mo radiation. Crystal data are listed in Table SM1. Selected distances and angles are collected in Table SM2.

4.4. Cell Viability. Cell viability was assessed using a crystal violet-based staining method. The cells $\left(3.5 \times 10^{5}\right)$ were seeded in $0.5 \mathrm{~mL}$ of completed medium in 24 multiwell dishes, treated with different amounts of CDDP, Cl-1, Cl-3, I-5, and I6 dissolved in the culture medium (RPMI) and fixed with $0.1 \%$ glutaraldehyde. After $30 \mathrm{~min}$, they were washed with distilled water and stained with $0.1 \%$ crystal violet. A colorimetric ELISA-based assay set at $595 \mathrm{~nm}$ was used to estimate the number of cells per well. MTS protocol was performed according to the manufacturer's instructions. $\mathrm{IC}_{50}$ were calculated by using the graph $\mathrm{PAD}$ prysme programme. We used nonlinear regression to fit the data to the log (inhibitor) versus response (variable slope).
4.5. Cell Cycle Analysis. MKN45 cells were seeded in 2.5 $\mathrm{mL}$ of RPMI $10 \%$ FBS in $\mathrm{p} 60$ plates and treated with solutions of the compounds following the established $\mathrm{IC}_{50}$. The cells were fixed, 24 and $48 \mathrm{~h}$ after the treatment was applied, using $70 \%$ ethanol in phosphate-buffered saline (PBS). To perform the DNA content analysis, the cells were centrifuged, the supernatant was discarded and $200 \mu \mathrm{l}$ of propidium iodide was added, and the tubes were incubated for $15 \mathrm{~min}$ in darkness. Finally, $200 \mu \mathrm{l}$ of a solution of RNase in PBS $(10 \mu \mathrm{l} / \mathrm{mL})$ was added to each tube. The cells were analyzed using a Becton Dickinson Flow Cytometer (Cowley, United Kingdom).

4.6. Western Blotting. The total protein extracts (WCE) were prepared using a lysis supplemented with phosphatase and protease inhibitors. WCE samples $(20 \mu \mathrm{g})$ were loaded in $15 \%$ (Bcl-2 family and caspase-3), 10\% (JNK, p38 and ERK), and $8 \%$ (PARP-1, p53, MCL1) SDS-PAGE polyacrylamide gels. Once the electrophoresis was completed, they were transferred to polyvinylidene difluoride membranes and immunodetection was done using the correspondent antibodies. The following antibodies were purchased from Santa Cruz Technology: PARP-1 (sc-7150), Mcl-1 (sc-819), JNK (sc827), p38 (sc-535), and ERK 1/2 (sc-154). The antibodies for Cleaved Caspase-3 (Asp175) (\#9661), Bax, BID, PUMA (\#12450), p-p38 (1:2000, \#4631), p-p53 (Ser15) (\#9284), and p53 (\#9282) were acquired from Cell Signaling Technology. The antibody for $p$-JNK was bought from Promega Corporation, Spain. Last, the antibody for tubulin (1:10 000) was acquired from Sigma-Aldrich. The standard working dilution for the antibodies was 1:1000, unless a different one was specified above.

\section{ASSOCIATED CONTENT}

\section{Supporting Information}

The Supporting Information is available free of charge at https://pubs.acs.org/doi/10.1021/acsomega.9b02831.

Synthesis and characterization of the platinum complexes, crystal data of trans- $\left[\mathrm{Pt}(9-\mathrm{EtG})_{2}(\mathrm{ipa})_{2}\right]\left(\mathrm{NO}_{3}\right)_{2}$, and selected bond distances and angles for the structure of trans- $\left[\mathrm{Pt}(9-\mathrm{EtG})_{2}(\mathrm{ipa})_{2}\right]\left(\mathrm{NO}_{3}\right)_{2}$ (PDF)

\section{AUTHOR INFORMATION}

\section{Corresponding Authors}

*E-mail: adoracion.gomez@uam.es (A.G.Q.).

*E-mail: misanchez@iib.uam.es (I.S.P.).

ORCID

Adoración G. Quiroga: 0000-0002-9261-9542

Isabel Sanchez Perez: 0000-0002-4829-201X

\section{Funding}

Authors A.G.Q., M.C., and A.A.-V. received funding from MINECO CTQ2015-68779-R. I.S.P. received funding from P17-01401 (supported by FEDER funds) from Fondo de Investigaciones Sanitarias, Instituto de Salud Carlos III, SpainNPL is a fellow of the Programa de Doctorado Biociencias Moleculares UAM, Madrid, Spain. NPL was supported by a fellowship Programa de Formación de Profesorado Universitario REF: FPU15/04669.

\section{Notes}

The authors declare no competing financial interest. 


\section{ACKNOWLEDGMENTS}

We thank SIDI-UAM (Servicio Interdepartamental Universidad Autonoma de Madrid) for their services. We thank Francisco Navas for his contributions with the experiments.

\section{ABBREVIATIONS}

CDDP, cisplatin; dma, dimethylamine; ipa, isopropylamine

\section{REFERENCES}

(1) Messori, L.; Casini, A.; Gabbiani, C.; Michelucci, E.; Cubo, L.; Ríos-Luci, C.; Padrón, J. M.; Navarro-Ranninger, C.; Quiroga, A. G. Cytotoxic Profile and Peculiar Reactivity with Biomolecules of a Novel Rule-Breaker Iodidoplatinum(II) Complex. ACS Med. Chem. Lett. 2010, 1, 381-385.

(2) Messori, L.; Cubo, L.; Gabbiani, C.; Álvarez-Valdés, A.; Michelucci, E.; Pieraccini, G.; Ríos-Luci, C.; León, L. G.; Padrón, J. M.; Navarro-Ranninger, C.; Casini, A.; Quiroga, A. G. Reactivity and Biological Properties of a Series of Cytotoxic $\mathrm{PtI}_{2}(\text { amine })_{2}$ Complexes, Either cis or trans Configured. Inorg. Chem. 2012, 51, $1717-1726$.

(3) Messori, L.; Marzo, T.; Gabbiani, C.; Valdes, A. A.; Quiroga, A. G.; Merlino, A. Peculiar Features in the Crystal Structure of the Adduct Formed between cis-PtI2(NH3) 2 and Hen Egg White Lysozyme. Inorg. Chem. 2013, 52, 13827-13829.

(4) Musumeci, D.; Platella, C.; Riccardi, C.; Merlino, A.; Marzo, T.; Massai, L.; Messori, L.; Montesarchio, D. A first-in-class and a fished out anticancer platinum compound: cis- $\left[\mathrm{PtCl}_{2}\left(\mathrm{NH}_{3}\right)_{2}\right]$ and cis$\left[\mathrm{PtI}_{2}\left(\mathrm{NH}_{3}\right)_{2}\right]$ compared for their reactivity towards DNA model systems. Dalton Trans. 2016, 45, 8587-8600.

(5) Štarha, P.; Vančo, J.; Trávníček, Z.; Hošek, J.; Klusáková, J.; Dvořák, Z. Platinum(II) Iodido Complexes of 7-Azaindoles with Significant Antiproliferative Effects: An Old Story Revisited with Unexpected Outcomes. PLoS One 2016, 11, No. e0165062.

(6) Parro, T.; Medrano, M. A.; Cubo, L.; Muñoz-Galván, S.; Carnero, A.; Navarro-Ranninger, C.; Quiroga, A. G. The second generation of iodido complexes: trans- $\left[\mathrm{PtI}_{2}(\right.$ amine $)($ amine $\left.)\right]$ bearing different aliphatic amines. J. Inorg. Biochem. 2013, 127, 182-187.

(7) Pajuelo-Lozano, N.; Bargiela-Iparraguirre, J.; Dominguez, G.; Quiroga, A. G.; Perona, R.; Sanchez-Perez, I. XPA, XPC, and XPD Modulate Sensitivity in Gastric Cisplatin Resistance Cancer Cells. Front. Pharmacol. 2018, 9, 1197.

(8) Cubo, L.; Casini, A.; Gabbiani, C.; Mastrobuoni, G.; Messori, L.; Jiménez-Barbero, J.; Navarro-Ranninger, C.; Quiroga, A. G. Solution Behaviour and Biomolecular Interactions of Two Cytotoxic transPlatinum(II) Complexes Bearing Aliphatic Amine Ligands. Chem.Eur. J. 2009, 15, 9139-9146.

(9) Zhang, Y.; Li, X.; Tan, S.; Liu, X.; Zhao, X.; Yuan, Z.; Nie, C. Mcl-1 expression and JNK activation induces a threshold for apoptosis in Bcl-xL-overexpressing hematopoietic cells. Oncotarget 2017, 8, 11042-11052.

(10) Wang, W.; Wang, Y.-Q.; Meng, T.; Yi, J.-M.; Huan, X.-J.; Ma, L.-P.; Tong, L.-J.; Chen, Y.; Ding, J.; Shen, J.-K.; Miao, Z.-H. MCL-1 degradation mediated by JNK activation via MEKK1/TAK1-MKK4 contributes to anticancer activity of new tubulin inhibitor MT189. Mol. Cancer Ther. 2014, 13, 1480-1491.

(11) Inoshita, S.; Takeda, K.; Hatai, T.; Terada, Y.; Sano, M.; Hata, J.; Umezawa, A.; Ichijo, H. Phosphorylation and inactivation of myeloid cell leukemia 1 by JNK in response to oxidative stress. J. Biol. Chem. 2002, 277, 43730-43734.

(12) Pesch, F. J.; Wienken, M.; Preut, H.; Tenten, A.; Lippert, B. Mono- and bis(9-ethylguanine) complexes of trans- $\left(\mathrm{CH}_{3} \mathrm{NH}_{2}\right)_{2} \mathrm{PtII}$. $\mathrm{X}$-ray structure of the 2:1 complex and redistribution of the 1:1 compound. Inorg. Chim. Acta 1992, 197, 243-249.

(13) Pérez, J. M.; Montero, E. I.; González, A. M.; Solans, X.; FontBardia, M.; Fuertes, M. A.; Alonso, C.; Navarro-Ranninger, C. X-ray structure of cytotoxic trans-[ $\mathrm{PtCl} 2$ (dimethylamine) (isopropylamine)]: Interstrand cross-link efficiency, DNA sequence specificity, and inhibition of the B-Z transition. J. Med. Chem. 2000, 43, 24112418.

(14) Sindellari, L.; Schöllhorn, H.; Thewalt, U.; Raudaschl-Sieber, G.; Lippert, B. Bis(9-ethylguaninium) and bis(9-ethylguanine) complexes of pt(II): preparation and crystal structures of cis$\left[\mathrm{Cl}_{2} \mathrm{Pt}\left(9-\mathrm{EtGH}_{2}\right)_{2}\right] \mathrm{Cl}_{2} \cdot 2 \mathrm{H}_{2} \mathrm{O}$ and cis- $\left[(\mathrm{pra})_{2} \mathrm{Pt}(9-\mathrm{EtGH})_{2}\right]\left(\mathrm{NO}_{3}\right)_{2}$ (pran-propylamine). Inorg. Chim. Acta 1990, 168, 27-32.

(15) Gregory, M. T.; Park, G. Y.; Johnstone, T. C.; Lee, Y.-S.; Yang, W.; Lippard, S. J. Structural and mechanistic studies of polymerase I. bypass of phenantfiplatin DNA damage. Proc. Natl. Acad. Sci. 2014, $111,9133-9138$.

(16) Riddell, I. A.; Johnstone, T. C.; Park, G. Y.; Lippard, S. J. Nucleotide Binding Preference of the Monofunctional Platinum Anticancer-Agent Phenanthriplatin. Chem.-Eur. J. 2016, 22, 75747581.

(17) Ghosh, S.; Mendoza, O.; Cubo, L.; Rosu, F.; Gabelica, V.; White, A. J. P.; Vilar, R. Assembly of palladium(II) and platinum(II) metallo-rectangles with a guanosine-substituted terpyridine and study of their interactions with quadruplex DNA. Chemistry 2014, 20, 4772-4779.

(18) Jiang, M.; Wei, Q.; Wang, J.; Du, Q.; Yu, J.; Zhang, L.; Dong, Z. Regulation of PUMA by p53 in cisplatin-induced renal cell apoptosis. Oncogene 2006, 25, 4056-4066.

(19) Perego, P.; Giarola, M.; Righetti, S. C.; Supino, R.; Caserini, C.; Delia, D.; Pierotti, M. A.; Miyashita, T.; Reed, J. C.; Zunino, F. Association between cisplatin resistance and mutation of p53 gene and reduced bax expression in ovarian carcinoma cell systems. Cancer Res. 1996, 56, 556-562.

(20) Xiang, W.; Yang, C.-Y.; Bai, L. MCL-1 inhibition in cancer treatment. OncoTargets Ther. 2018, 11, 7301-7314. 